\title{
The Results of Adjuvant and Salvage Radiotherapy Following Radical Prostatectomy
}

\author{
Radikal Prostatektomi Sonrası Adjuvan ve Kurtarma Radyoterapi \\ Sonuçları
}

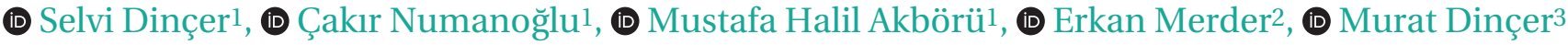

${ }^{1}$ University of Health Sciences Turkey, Prof. Dr. Cemil Taşçığlu City Hospital, Clinic of Radiation Oncology, İstanbul, Turkey

${ }^{2}$ University of Health Sciences Turkey, Prof. Dr. Cemil Taşçığlu City Hospital, Clinic of Urology, İstanbul, Turkey

${ }^{3}$ University of Health Sciences Turkey, İstanbul Bağcllar Training and Research Hospital, Clinic of Urology, İstanbul, Turkey

Abstract

Objective: The aim of the study is to evaluate the contribution of postoperative adjuvant radiotherapy (ART) and salvage radiotherapy (SRT) to oncological outcomes and side effects related to treatment in prostate cancer patients with adverse prognostic factors.

Method: Between January 2000 and January 2020, 105 patients who received the diagnosis of prostate cancer and underwent ART or SRT in our clinic after open or robotic-assisted radical prostatectomy were evaluated retrospectively and 93 patients whose follow-ups were still ongoing were included in the study. Fifty-two patients received ART and 41 patients received SRT. External beam radiotherapy (EBRT) was applied to prostate bed (PB) with a median EBRT of 70 Gy (66-72 Gy) and/or pelvic lymphatics with 50 Gy. Biochemical relapse-free survival (bRFS) and treatment-related acute and late gastrointestinal (Gl) and genitourinary (GU) toxicities were evaluated. The Mann-Whitney $U$ and chi-square tests were used for univariate analysis to analyze clinicopathological variables associated with biochemical relapse-free and overall survival and to evaluate side effects. Logistic regression model was used for multivariate analysis to investigate the risk factors associated with toxicities.

Results: The median age of the patients included in the study was 64 (5082) years. The median follow-up period of the entire patient population was 30 months (range, 3-234 months). Adjuvant RT was applied to 52 patients with adverse pathological features such as postoperative surgical margin positivity, extracapsular extension and seminal vesicle involvement, while SRT was applied to 41 patients with a prostate-specific antigen level $\geq 0.2 \mathrm{ng} / \mathrm{mL}$ detected during follow-up and considered to have biochemical relapse. bRFS rates at 3 years were detected as $100 \%$ in the ART and $97.4 \%$ in the SRT arm. Acute and late side effects were

\section{Öz}

Amaç: Çalışmanın amacı, advers prognostik faktörlere sahip prostat kanserli hastalarda postoperatif adjuvan radyoterapi (ART) ve salvage radyoterapinin (SRT) onkolojik sonuçlara katkısını ve tedaviye bağlı yan etkileri değerlendirmektir.

Yöntem: Ocak 2000-Ocak 2020 yılları arasında prostat kanseri tanısı alan ve açık veya robotic-assisted radikal prostatektomi sonrası kliniğimizde ART veya SRT uygulanan 105 hasta retrospektif olarak değerlendirilmiş ve takipleri devam eden 93 hasta çalışmaya dahil edilmiştir. Elli iki hastaya ART ve 41 hastaya da SRT tedavisi uygulanmıştır. Eksternal RT prostat yatağı medyan 70 Gy (66-72 Gy) \pm pelvik lenfatiklere 50 Gy olacak şekilde uygulandı. Biyokimyasal nükssüz sağkalım (bPFS) ve tedaviye bağlı akut ve geç gastrointestinal (GI) ve genitoüriner (GU) toksisiteler değerlendirildi. bPFS ve tüm sağkalım ile ilişkili klinopatolojik değişkenleri analiz etmek ve yan etkileri değerlendirmek için Mann-Whitney $U$ ve tek değişkenli analiz için ki-kare testi kullanıldı. Toksisite ile ilişkili risk faktörlerini araştırmak amacıyla çok değişkenli analiz için lojistik regresyon modeli kullanıldı.

Bulgular: Çalışmaya dahil edilen hastaların medyan yaşı 64 (50-82) yıl idi. Tüm hasta popülasyonu için medyan takip süresi 30 ay (3-234 ay) idi. Postoperatif olarak cerrahi sınır pozitif, ekstrakapsüler ve seminal vesikül tutulumu olan advers patolojik özelliklere sahip 52 hastaya adjuvan RT uygulanırken, takip esnasında prostata özgü antijen düzeyi $\geq 0,2 \mathrm{ng} /$ $\mathrm{mL}$ olan ve biyokimyasal nüks kabul edilen 41 hastaya SRT uygulandı. Üç yıllık bPFS ART kolunda \%100 ve SRT kolunda \%97,4 olarak tespit edildi. Akut ve geç yan etkiler Radiation Therapy Oncology Group/ European Organization for Research and Treatment of Cancer sistemine göre değerlendirildi ve ART ve SRT uygulanan hastalarda akut ve geç GI ve GU yan etkiler benzer bulundu. Akut toksisite gelişmesini predikte

Address for Correspondence: Selvi Dinçer, University of Health Sciences Turkey, Prof. Dr. Cemil Taş̧̧ığlu City Hospital, Clinic of Radiation Oncology, istanbul, Turkey

E-mail: dincerselvi@yahoo.com ORCID: orcid.org/0000-0002-7177-9539 Received: 16.11.2020 Accepted: 07.01.2021

Cite this article as: Dinçer S, Numanoğlu Ç, Akbörü MH, Merder E, Dinçer M. The Results of Adjuvant and Salvage Radiotherapy Following Radical Prostatectomy. Bagcilar Med Bull 2021;6(2):125-133

${ }^{\circ}$ Copyright 2021 by the Health Sciences University Turkey, Bagcilar Training and Research Hospital Bagcilar Medical Bulletin published by Galenos Publishing House. 


\section{Abstract}

evaluated according to the Radiation Therapy Oncology Group/European Organization for Research and Treatment of Cancer system, and acute and late GI and GU side effects were found to be similar in patients who underwent ART or SRT. In the multivariate logistic regression analysis in which the factors predicting the development of acute toxicity were investigated, the risk of developing acute toxicity was found to be higher in patients with lymph node involvement $(p=0.047)$ and those who underwent whole pelvic RT (WPRT) compared to those who received RT applied only to PB $(p=0.002)$. When the patients who received WPRT using volumetric arc therapy (VMAT) were compared with those who had radiotherapy delivered only to $\mathrm{PB}$, grade $\geq 2$ acute $\mathrm{Gl}$ side effects were detected in $4.2 \%$ and $1.4 \%$ of the patients, respectively $(p=0.002)$. On the other hand, grade $\geq 2$ acute GU side effects were found in $12.5 \%$ and $5.7 \%$ of the patients, respectively. When WPRT vs only PB was compared, any statistically significant difference was not found in terms of late toxicity.

Conclusion: Postoperative radiotherapy improves biochemical relapsefree survival in patients with adverse prognostic factors. Despite low incidence of side effects, postoperative pelvic radiotherapy results in significant increases in the acute gastrointestinal toxicity rates. Advanced treatment techniques such as VMAT should be considered in pelvic radiotherapy so as to reduce the incidence of these side effects. It should be noted that in order to improve the quality of life of the patients, timely administration of early SRT showed comparable cancer control rates while reducing potential overtreatment toxicity.

Keywords: Adjuvant radiotherapy, adverse prognostic factors, prostate cancer, salvage radiotherapy

\section{Öz}

eden faktörlerin araştıııldığı çok değişkenli lojistik regresyon analizinde lenf nodu tutulumu olan $(p=0,047)$ ve pelvik RT (WPRT) uygulanan hastalarda akut toksisite gelişme riski sadece prostat yatağı (PB) RT uygulananlara göre daha yüksek bulundu $(p=0,002)$. Volümetrik arc tekniği kullanılarak (VMAT) uygulanan WPRT vs PB RT uygulanan hastalar karşılaştıııldığında, zgrade 2 akut GI yan etki sırasıyla \%4,2 ve $\% 1,4$ olarak tespit edilirken, $\geq$ grade 2 akut GU yan etki ise $\% 12,5$ ve $\% 5,7$ olarak bulundu $(p=0,002)$. WPRT vs PB karşılaştıııldığında geç toksisite açısından istatistiksel olarak anlamlı bir fark bulunmadı.

Sonuç: Postoperatif radyoterapi, kötü prognostik faktörü olan hastalarda bPFS'yi artırır. Postoperatif pelvik radyoterapiye bağlı yan etkilerin görülme sıklığı az olsa da, Gl toksisite oranı belirgin derecede artmaktadır. VMAT gibi ileri tedavi teknikleri pelvik radyoterapinin yan etkilerini azaltmak için uygulanmalıdır. Hastaların hayat kalitesini artırmak için, zamanında uygulanan erken kurtarma radyoterapisi tedaviye bağlı yan etkileri azaltırken hastalık kontrolünü de artırır.

Anahtar kelimeler: Adjuvan radyoterapi, kurtarma radyoterapisi, olumsuz prognostik faktörler, prostat kanseri

\section{Introduction}

As curative treatment alternatives, radiotherapy (RT) and radical prostatectomy (RP) are prevalently accepted and used as therapeutic options in the treatment of localized prostate cancer $(\mathrm{PCa})$. Post-treatment outcomes of these treatment alternatives are comparable; however, vast majority of patients who previously underwent RP will ultimately undergo immediate (adjuvant) or delayed (salvage) RT (1). As demonstrated in several studies, nearly one-third of the patients undergoing RP will develop postoperative biochemical relapse following RP (2). For high-risk postprostatectomy patients with positive surgical margins (PSM), seminal vesicle involvement (SVI), extracapsular (EC) involvement, high pathologic T-stage or higher Gleason score (GS), ART is often signified depending on postoperative pathologic findings. In PCa patients with adverse pathologic features following RP, ART reduces the biochemical failure by improving clinical outcomes (3). SRT is also used in the treatment of cases with biochemical relapse detected during follow-up. The presence of two rising PSA levels $\geq 0.2 \mathrm{ng} / \mathrm{mL}$ is considered as postoperative biochemical relapse (4). Controversial opinions have been put forth regarding the application of ART or SRT due to an increase in PSA levels. However, RT is directed at the prostatic fossa and/or pelvic lymph nodes (PLNs) related to the pathologic adverse factors which may be combined with androgen deprivation therapy (ADT) $(5,6)$. Application of ART and elective RT targeting pelvic nodes in clinically node-negative patients without any risk of developing potential recurrences in the future remains to be a debatable issue. Indeed, due to its potential GU and GI side effects, RT may be an unnecessary treatment modality for these patients (7).

Biochemical progression-free survival (bPFS) or overall survival (OS) rates, and the increasing of side effects related to ART vs SRT have not been conclusively determined yet.

Three large randomized controlled trials (EORTC 22911, SWOG 8794 and ARO 96-02) enrolling more than 1.700 patients compared ART to watchful waiting and all of these studies revealed a significant benefit favoring ART in terms of biochemical recurrence-free survival (bRFS) rates, while only one of these trials also demonstrated an increase in OS rates in the ART arm (8-10). However, in the ART arm, grade $\geq 2 \mathrm{GI}$ and GU toxicities were observed (11).

Unfortunately, any randomized studies have not compared ART with SRT. Biochemical and OS benefits of SRT in 
a subgroup of patients have been revealed in many retrospective series $(12,13)$. In numerous studies, significant differences have not been detected between safety profiles of postoperatively administered ART and SRT $(14,15)$.

Even if the most advanced techniques have been used, relatively higher doses of the pelvic field RT delivered outside the prostate bed increased incidence rates of GI and GU side effects. Indeed, an increased rate of toxicity following WPRT was reported previously (16). There are no data available on patients treated with elective WPRT compared with PB-RT not targeting pelvic fields.

Therefore, the choice between RP plus ART or SRT with or without ADT depends on their treatment-related toxicity and personal preferences.

The objective of this study is to compare the oncological results and treatment-related toxicity with the diagnosis of PCa patients treated with ART or SRT after RP performed in a single center.

\section{Materials and Methods}

Between January 2000 and January 2020, 105 patients who were treated with ART or SRT after RP in the Radiation Oncology Clinic of University of Health Sciences Turkey, Prof. Dr. Cemil Taşçıoğlu City Hospital were retrospectively evaluated. Patient information was obtained from patient files and hospital data system. Twelve patients were excluded from the study because they were lost to follow-up. Ninety-three patients with completed data, who had surgical margin (SM) positivity, SV or EC involvement, regardless of tumor stage, or biochemical recurrence at follow-up, were included in the study.

Preoperatively, all patients were evaluated based on medical history, clinical assessment, serum PSA and testosterone levels, transrectal ultrasound and abdominopelvic computed tomography (CT)/magnetic resonance imaging (MRI) and bone scintigraphy findings. The ART group consisted of patients with postoperative PSA $\leq 0.2 \mathrm{ng} / \mathrm{mL}$ whose RT was initiated within 6 months after surgery. The SRT group consisted of patients with a postoperative PSA level $\geq 0.2 \mathrm{ng} / \mathrm{mL}$ during follow-up and considered to have biochemical recurrence. ART was applied to 52 and SRT to 41 patients.

Patients with positive pelvic nodes or carrying a risk (>15\%) of pelvic node involvement defined according to the Roach formula underwent pelvic RT (17).
None of the patients underwent hormonal therapy before prostatectomy. ADT consisting of gonadotropinreleasing hormone agonists or antiandrogen therapy was administered in the presence of adverse pathologic features including T3/4 stage, EC extension (ECE), and SVI, GS $\geq 7$, PSA $>20 \mathrm{ng} / \mathrm{mL}$ before surgery, relapse or lymph node involvement.

Patients were treated using the volumetric arc therapy (VMAT) technique delivered by a linear accelerator (Varian RapidArc, Palo Alto, CA, USA). All patients underwent CT simulation with a full bladder and empty rectum in the supine position placed in an appropriate fixation device with knee and foot support. CT data sets were sent for contouring on the Eclipse treatment planning system (VarianMedical System, Palo Alto, CA, USA) and then using DICOM RT (digital imaging and communication in medicine) format, they were exported directly to the treatment with the trilogy linear accelerator. For all patients, clinical target volume 1 (CTV 1) included prostate bed and the seminal vesicles bed, and CTV2, obturator, presacral, external and internal lymph nodes below the aortic bifurcation. The CTV1 was contoured using the Radiation Therapy Oncology Group consensus guidelines modified according to surgical and pathologic findings (18). The planning target volume1 (PTV1) was defined as CTV 1 with an additional margin of $1 \mathrm{~cm}$ in all directions except 6 $\mathrm{mm}$ posteriorly so as to reduce the risk of rectal toxicity. PTV2 was achieved adding a $7 \mathrm{~mm}$ isotropic margin to CTV2. The rectum, bladder, femoral heads, large and small bowel, and penile bulb were outlined as organs at risk. The course of RT consisted of 33-36 fractions of 2 Gy daily for a total dose of 66-72 Gy to PTV1. If pelvic nodes were to be irradiated, a total dose of $50 \mathrm{~Gy}$ in 25 fractions with a single fractional dose of $2 \mathrm{~Gy}$ was delivered.

\section{Follow-up and Toxicity Evaluation}

Patients were observed for 4 weeks after the completion of RT, then every 3-6 months with physical examination, PSA measurements, and assessments of toxicity. Acute toxicities were retrospectively graded based on physicians' notes taken during the treatment and within 6 months after RT using the Radiation Therapy Oncology Group/ European Organization for Research and Treatment of Cancer (RTOG/EORTC) guidelines (19). Late toxicities were defined as those occurring 6 months after RT and scored using the RTOG and EORTC scale (Table 1).

Primary endpoints were acute and late toxicities. Secondary endpoints were bRFS and OS. This retrospective data 
analysis was approved by the ethics committee of our hospital. All patients signed a written informed consent.

\section{Statistical Analyses}

The prognostic factors such as age, comorbidity, disease stage, GS, baseline pre-RT and post-RT PSA levels, status of SM, ADT and RT technique and dose were comparatively analyzed between ART and SRT using SPSS v21 (IBM Inc. USA) program. For categorical variables, the numbers and percentages, and for continuous variables median and range values were reported. The Mann-Whitney U test, chi-square test or Fisher's Extact test were used to compare intergroup differences. Logistic regression models were used in order to investigate the risk factors associated with toxicities. An overall p-value of less than 0.05 was considered to have statistical significance.

\section{Results}

\section{Patient Characteristics}

The median age of the patients included in the study was $64(50-82)$ years. Comorbid disease was present in 52.7\% of the patients who underwent RT after RP, and frequently hypertension (36.96\%) and diabetes mellitus (16.30\%) were found. The median follow-up of the entire patient population was 30 months (3-234) following RT.
Fifty-two patients were treated with ART and 41 with SRT. RT was initiated within postoperative 1-6 months (median 4 months) in the ART group. While SRT was maintained for 6-194 months (median 37 months) following prostatectomy. Pre-RT median PSA values were $0.016 \mathrm{ng} / \mathrm{mL}$ (0.001-1.90 $\mathrm{ng} / \mathrm{mL})$ in the ART and $0.60 \mathrm{ng} / \mathrm{mL}(0.21-12.01 \mathrm{ng} / \mathrm{mL})$ in the SRT group.

Seventy-two patients had open RP and 21 had robotassisted prostatectomy. Lymph node dissections were performed in a total of 41 patients, and the median number of 7 (1-24) lymph nodes were removed. The most frequent SM positivity was detected in the posterior lobe $(36.11 \%)$ and apex (15.28\%) of the prostate.

\section{ART vs SRT}

A higher percentage of patients treated with SRT had a GS of $8-10$ (26.8\% vs $19.2 \%)$ and more frequently had adverse pathologic factors compared to those receiving ART. Median values for rates of ECE positivity $(48.1 \%$ and $34.1 \%$, $\mathrm{p}=0.033)$, SVI $(15.4 \%$ and $19.5 \%, \mathrm{p}=0.783)$, SM positivity (92.6\% and $53.7 \%, \mathrm{p}<0.0001)$, and lymph node involvement (23.5\% and $26.8 \%, \mathrm{p}=0.850$ ) were determined in the ART and SRT groups, respectively (Table 2).

In the ART and SRT groups of patients, PLNs were irradiated in 13 (25\%) and $11(26.8 \%)$ patients, while only PB-RT was

Table 1. RTOG acute and RTOG/EORTC late radiation morbidity scoring criteria

\begin{tabular}{|c|c|c|c|c|}
\hline & Acute & & Late & \\
\hline $\begin{array}{l}\text { Organ } \\
\text { tissue }\end{array}$ & Lower gastrointestinal & Genitourinary & Lower gastrointestinal & Genitourinary \\
\hline Grade 0 & No change & No change & None & None \\
\hline Grade 1 & $\begin{array}{l}\text { Increased frequency or change in } \\
\text { quality of bowel habits not requiring } \\
\text { medication/rectal discomfort not } \\
\text { requiring analgesics }\end{array}$ & $\begin{array}{l}\text { Frequency of urination or nocturia } \\
\text { twice pretreatment habit/dysuria, } \\
\text { urgency not requiring medication }\end{array}$ & $\begin{array}{l}\text { Mild diarrhea, mild cramping, } \\
\text { bowel movement } 5 \text { times } \\
\text { daily, slight rectal discharge } \\
\text { or bleeding }\end{array}$ & $\begin{array}{l}\text { Slight epithelial atrophy, } \\
\text { minor telangiectasia } \\
\text { (microscopic hematuria) }\end{array}$ \\
\hline Grade 2 & $\begin{array}{l}\text { Diarrhea requiring parasympatholytic } \\
\text { drugs (e.g., diphenoxylate/mucus } \\
\text { discharge not necessitating sanitary } \\
\text { pads/rectal or abdominal pain } \\
\text { requiring analgesics }\end{array}$ & $\begin{array}{l}\text { Frequency of urination or nocturia at } \\
\text { longer than hourly intervals Dysuria, } \\
\text { urgency, bladder spasm requiring } \\
\text { local anesthetic (e.g., pyridium) }\end{array}$ & $\begin{array}{l}\text { Moderate diarrhea and colic, } \\
\text { bowel movement }>5 \text { times } \\
\text { daily, excessive rectal mucus } \\
\text { or intermittent bleeding }\end{array}$ & $\begin{array}{l}\text { Moderate urinary } \\
\text { frequency, generalized } \\
\text { telangiectasia, } \\
\text { intermittent macroscopic } \\
\text { hematuria }\end{array}$ \\
\hline Grade 3 & $\begin{array}{l}\text { Diarrhea requiring parenteral } \\
\text { support/severe mucous or blood } \\
\text { discharge necessitating sanitary } \\
\text { pads/abdominal distention (plain } \\
\text { abdominal radiograph demonstrates } \\
\text { distended bowel loops) }\end{array}$ & $\begin{array}{l}\text { Urinary frequency with urgency and } \\
\text { nocturia at hourly or more frequent } \\
\text { intervals/dysuria, pelvic pain, or } \\
\text { bladder spasm requiring regular, } \\
\text { frequent narcotic analgesics/gross } \\
\text { hematuria with/without clot passage }\end{array}$ & $\begin{array}{l}\text { Obstruction or bleeding, } \\
\text { requiring surgery }\end{array}$ & $\begin{array}{l}\text { Severe frequency } \\
\text { and dysuria, severe } \\
\text { telangiectasia frequent } \\
\text { hematuria, reduction in } \\
\text { bladder capacity }\end{array}$ \\
\hline Grade 4 & $\begin{array}{l}\text { Acute or subacute obstruction, } \\
\text { fistula or perforation, gastrointestinal } \\
\text { bleeding requiring transfusion, } \\
\text { abdominal pain or tenesmus } \\
\text { requiring tube decompression or } \\
\text { bowel diversion }\end{array}$ & $\begin{array}{l}\text { Hematuria requiring transfusion/ } \\
\text { acute bladder obstruction not } \\
\text { secondary to clot passage, } \\
\text { ulceration, or necrosis }\end{array}$ & Necrosis/perforation fistula & $\begin{array}{l}\text { Necrosis/contracted } \\
\text { bladder(reduced bladder } \\
\text { capacity) }\end{array}$ \\
\hline
\end{tabular}


delivered in 39 (75\%) and 30 (73.2\%) patients, respectively. In patients who underwent pelvic field RT and postoperative PB-RT, the median pre-RT PSA values were $0.147 \mathrm{ng} / \mathrm{mL}$ (0.001-7.710) and 0.134 (0.003-12.010), respectively.

Hormonal therapy (HT) was used in $61.5 \%$ and $56.1 \%$ of the patients undergoing ART and SRT, respectively. The median duration of HT was 12 months (6-36 months) in the ART and SRT groups. RT doses $<70$ Gy were administered to $29.4 \%$ and $36.6 \%$, and $\geq 70$ Gy were administered to $70.6 \%$ and $63.4 \%$ of the patients in the ART, and SRT groups, respectively

At the time of analysis, only one patient had a biochemical relapse in the SRTgroup (2.43\%) following previous RT after 36 months and received hormone therapy.

\section{Treatment-related Toxicities}

Acute GI side effects were not observed in $88.5 \%$ and $85.4 \%$ of the patients in the ART and SRT groups, respectively. In only one patient in both ART, and SRT groups, grade 2 , and 3 side effects were observed ( $p=0.527$ ).

\begin{tabular}{|c|c|c|c|}
\hline Characteristics & $\begin{array}{l}\text { SRT } \\
n=41\end{array}$ & $\begin{array}{l}\text { ART } \\
n=52\end{array}$ & $\mathbf{p}$ \\
\hline Age, year, median (range) & $66(53-82)$ & $64(50-76)$ & 0.100 \\
\hline$\leq 64$, year $\mathrm{n}(\%)$ & $17(41.5)$ & $30(57.7)$ & 0.146 \\
\hline$>64$, year, n (\%) & $24(58.5)$ & $22(42.3)$ & \\
\hline Comorbidity, n (\%) & $24(58.5)$ & $25(48.1)$ & 0.403 \\
\hline Pre-RT PSA, median (range) & $0.60(0.21-12.01)$ & $0.016(0.001-1.90)$ & $<0.0001$ \\
\hline Post-RT PSA, median (range) & $0.06(0.003-9.59)$ & $0.008(0.003-0.29)$ & $<0.0001$ \\
\hline RT dose, n (\%) & - & - & 0.158 \\
\hline$<70$ Gy & $15(36.6)$ & $15(29.4)$ & \\
\hline$\geq 70$ Gy & $26(63.4)$ & $36(70.6)$ & \\
\hline Surgical margin positivity $\mathrm{n}(\%)$ & $22(53.7)$ & $50(96.2)$ & $<0.0001$ \\
\hline SV Involvement n (\%) & $8(19.5)$ & $8(15.4)$ & 0.783 \\
\hline ECE, positivity n (\%) & $14(34.1)$ & $25(48.1)$ & 0.033 \\
\hline Gleason score, n (\%) & - & - & 0.069 \\
\hline 6 & $13(31.7)$ & $9(17.3)$ & - \\
\hline $3+4$ & $9(22.0)$ & $25(48.1)$ & - \\
\hline $4+3$ & $8(19.5)$ & $8(15.4)$ & - \\
\hline 8-10 & $11(26.8)$ & $10(19.2)$ & - \\
\hline Hormonal therapy $\mathrm{n}(\%)$ & $23(56.1)$ & $32(61.5)$ & 0.673 \\
\hline Duration of hormonal therapy, months, median (range) & $12(6-30)$ & $12(6-36)$ & 0.849 \\
\hline Lymph node involvement, $\mathrm{n}(\%)$ & $11(26.8)$ & $12(23.5)$ & 0.850 \\
\hline RT field & - & - & 0.158 \\
\hline Whole pelvic fields & $11(26.8)$ & $13(25.0)$ & - \\
\hline Prostate bed & $30(73.2)$ & $39(75.0)$ & - \\
\hline
\end{tabular}

Acute GU system side effects were not observed in $50 \%$, and $53.7 \%$ of the patients in the ART and SRT groups, respectively. Grade 2 and 3 side effects were seen in $5.8 \%$ vs $7.3 \%$, and $0 \%$ vs $2.4 \%$ of the patients in the ART and SRT groups, respectively $(\mathrm{p}=0.628)$ (Table 3$)$.

Grade 2 and 3 late GI side effects were detected at the rates of $1.9 \%$ and $1.9 \%$ in the ART group, and $4.9 \%$ and $0 \%$ in the SRT group, while they were not observed in $94.2 \%$ and $95.1 \%$ of the patients, respectively $(\mathrm{p}=0.532$ ). Late GU side effects were not observed in $76.9 \%$ and $82.9 \%$ of the patients, while grade $2 \mathrm{GU}$ side effects were observed in $1.9 \%$ vs $2.4 \%$ and grade 3 in $9.6 \%$ vs $4.9 \%$ of the patients in the ART and SRT groups, respectively ( $\mathrm{p}=0.829$ ) (Table 3).

In the multivariate logistic regression analysis in which the factors affecting the development of acute toxicity were investigated, the risk of developing acute toxicity was found to be higher in patients who underwent pelvic RT compared to those who did not ( $\mathrm{p}=0.002)$ (Table 4). In addition, the risk of developing acute toxicity was found

SV: Seminal vesicle, ECE: Extracapsular invasion, RT: Radiotherapy, ART: Adjuvant radiotherapy, SRT: Salvage radiotherapy, PSA: Prostate-specific antigen 
to be higher in patients with lymph node involvement $(p=0.047)$. When the factors affecting the development of late toxicity were investigated, any statistically significant factor was not found (Table 5).

\begin{tabular}{|c|c|c|c|c|}
\hline & & & & $\mathbf{p}$ \\
\hline \multirow{10}{*}{ ACUTE } & GI. N (\%) & SRT & ART & 0.527 \\
\hline & Absent & $35(85.4)$ & $46(88.5)$ & - \\
\hline & Grade 1 & $5(12.2)$ & $5(9.6)$ & - \\
\hline & Grade 2 & $0(0.0)$ & $1(1.9)$ & - \\
\hline & Grade 3 & $1(2.4)$ & $0(0.0)$ & - \\
\hline & GU. n (\%) & SRT & ART & 0.628 \\
\hline & Absent & $22(53.7)$ & $26(50.0)$ & - \\
\hline & Grade 1 & $15(36.6)$ & $23(44.2)$ & - \\
\hline & Grade 2 & $3(7.3)$ & $3(5.8)$ & - \\
\hline & Grade 3 & $1(2.4)$ & $0(0.0)$ & - \\
\hline \multirow{10}{*}{ LATE } & GI. n (\%) & SRT & ART & 0.532 \\
\hline & Absent & 39 (95.1) & $49(94.2)$ & - \\
\hline & Grade 1 & $0(0.0)$ & $1(1.9)$ & - \\
\hline & Grade 2 & $2(4.9)$ & $1(1.9)$ & - \\
\hline & Grade 3 & $0(0.0)$ & $1(1.9)$ & - \\
\hline & GU. n (\%) & SRT & ART & 0.829 \\
\hline & Absent & $34(82.9)$ & $40(76.9)$ & - \\
\hline & Grade 1 & $4(9.8)$ & $6(11.5)$ & - \\
\hline & Grade 2 & $1(2.4)$ & $1(1.9)$ & - \\
\hline & Grade 3 & $2(4.9)$ & $5(9.6)$ & - \\
\hline
\end{tabular}

Gl: Gastrointestinal, SRT: Salvage radiotherapy ART: Adjuvant radiotherapy, GU: Genitourinary

\begin{tabular}{|c|c|c|c|c|}
\hline Characteristics & & HR & $95 \% \mathrm{Cl}$ & $\mathbf{p}$ \\
\hline Age & & 1.04 & $0.98-1.10$ & 0.259 \\
\hline DM & & 0.69 & $0.28-1.66$ & 0.405 \\
\hline HPT & & 1.14 & $0.58-2.25$ & 0.702 \\
\hline Post-op PSA & & 1.12 & $0.91-1.38$ & 0.297 \\
\hline Pre-RT PSA & & 1.01 & $0.87-1.18$ & 0.856 \\
\hline Surgical margin positivity & & 0.59 & $0.23-1.57$ & 0.293 \\
\hline Hormonal therapy & & 1.69 & $0.83-3.44$ & 0.149 \\
\hline WPRT & & 4.17 & $1.72-10.00$ & $0.002^{*}$ \\
\hline Gleason score $\geq 8$-10 & & 1.75 & $0.78-3.83$ & 0.164 \\
\hline Lymph node involvement & & 2.63 & $1.01-7.14$ & $0.047^{*}$ \\
\hline \multirow[t]{2}{*}{ Type of surgery } & Open (ref) & 1 & - & - \\
\hline & Robotic & 1.05 & $0.42-2.65$ & 0.912 \\
\hline \multirow[t]{2}{*}{ Type of RT } & ART (ref) & 1 & - & - \\
\hline & SRT & 0.48 & $0.21-1.08$ & 0.075 \\
\hline
\end{tabular}

DM: Diabetes mellitus, HPT: Hypertension, RT: Radiotherapy, WPRT: Whole pelvic radiotherapy, PSA: Prostate-specific antigen, Cl: Confidence interval, HR: Hazard ratio

\section{Discussion}

This study evaluated the effectiveness of local and pelvic RT in PCa patients with adverse pathologic features following $\mathrm{RP}$, acute and late GI and GU toxicity profiles.

The American Urological Association (AUA) and the American Society for Radiation Oncology (ASTRO) have recommended ART in patients with SVI, PSM and ECE while the application of SRT is suggested for the treatment of the patients with biochemical relapse described as two rising PSA levels $\geq 0.2 \mathrm{ng} / \mathrm{mL}$ following $\mathrm{RP}(20,21)$.

Three randomized controlled trials (EORTC22911, SWOG8794, ARO96-02/AUO-AP09/95) with long-term follow-up results demonstrated improvement in bPFS ( $<<0.00001$ ) with ART to the prostatic bed vs watchful waiting in the patients with adverse pathologic features such as PSM, SVI or ECE (8-10). Only SWOG 8.794 trial demonstrated an improvement in OS (9). In the observational arms, approximately $40 \%$ of patients never had recurrences, thus indicating the possibility of overtreatment with ART in this group of patients. However, the number of treatment-related side effects increased, which was associated with improper patient selection. ART was associated with higher toxicity levels when compared with the observational arm (grade $\geq 2$ GI toxicities: $2 \%$ vs $1 \%$ and grade $\geq 2$ GU toxicities: $17 \%$ vs $10 \%$ ) in these trials (22).

\section{Table 5. Factors affecting late side effects}

\begin{tabular}{|c|c|c|c|c|}
\hline Characteristics & & HR & $95 \% \mathrm{Cl}$ & $\mathbf{p}$ \\
\hline Age & & 1.02 & $0.95-1.10$ & 0.524 \\
\hline DM & & 0.12 & $0.01-1.07$ & 0.057 \\
\hline HPT & & 1.15 & $0.44-3.00$ & 0.776 \\
\hline Post-op PSA & & 0.78 & $0.42-1.52$ & 0.493 \\
\hline Pre-RT PSA & & 1.03 & $0.81-1.29$ & 0.834 \\
\hline $\begin{array}{l}\text { Surgical margin } \\
\text { positivity }\end{array}$ & & 0.36 & $0.11-1.16$ & 0.087 \\
\hline Hormonal therapy & & 0.95 & $0.35-2.58$ & 0.913 \\
\hline Pelvic RT & & 3.33 & $0.90-12.50$ & 0.070 \\
\hline Gleason score $\geq 8-10$ & & 2.00 & $0.61-6.55$ & 0.256 \\
\hline $\begin{array}{l}\text { Lymph node } \\
\text { involvement }\end{array}$ & & 1.79 & $0.44-7.14$ & 0.419 \\
\hline \multirow[t]{2}{*}{ Type of surgery } & Open (ref) & 1 & - & - \\
\hline & Robotic & 1.77 & $0.57-5.48$ & 0.323 \\
\hline \multirow[t]{2}{*}{ Type of RT } & ART (ref) & 1 & - & - \\
\hline & SRT & 0.42 & $0.14-1.24$ & 0.116 \\
\hline
\end{tabular}

DM: Diabetes mellitus, HPT: Hypertension, RT: Radiotherapy, ART: Adjuvant radiotherapy, SRT: Salvage radiotherapy, Cl: Confidence interval, PSA: Prostatespecific antigen, HR: Hazard ratio 
Application of postoperative ART or SRT is still controversial in the patient group with high risk of biochemical relapse after surgery while very recently three randomized studies GETUG-AFU 17, RAVES and RADICALS have been evaluated in a systematic review and meta-analysis that will enable us to decide the appropriate time of RT after surgery (23-25). This prospectively designed meta-analysis has revealed that ART does not improve PSA-related eventfree survival but urinary and intestinal adverse effects were observed with a higher rate in patients who underwent ART (26). Our data have shown that the patients receiving SRT had very low biochemical relapse rates $(97.57 \%)$ with acceptable side effects. It should be noted that in order to improve the patients' quality of life, timely administration of early SRT ensures comparable cancer control rates while reducing potential overtreatment toxicity.

Jereczek-Fossa et al. (27) applied ART in 258 patients, and SRT in 173 patients using conformal technique, and did not observe any difference between both treatment modalities as for acute and late GI toxicities. However, higher rates of grade 3-4 acute urinary toxicities were reported in the ART group (27). In multivariate analysis performed for the pooled multi-institutional trials have shown side effects in late GU and GI in postprostatectomy patients undergoing ART or SRT, higher rates of grade $\geq 2$ GU toxicity were detected in the ART group (28). Although modern RT techniques including intensity- modulated radiation therapy (IMRT) were not used and 2-dimensional (2-D) or 3-dimensional (3-D) conformal RT (CRT) treatment planning was employed in these studies, there was no difference in GI and GU side effects between the two groups. In our study, as in the study of Jereczek-Fossa et al. (27), no statistical difference was observed between the ART and SRT groups in terms of GI side effects, while it was determined that late grade $3 \mathrm{GU}$ side effects were more frequently seen in the ART arm rather than SRT arm without any statistically significant intergroup difference.

Some authors have considered lower PSA levels $(<0.01$ $\mathrm{ng} / \mathrm{mL}$ ) as an indicative of subclinical disease. Abugharib et al. (29) explored the best timing of SRT following RP based on the lowest levels of PSA and observed that PSA levels detected before SRT strongly correlated with bRFS. Higher PSA levels before SRT (0.01-0.2, 0.2-0.5 and $>0.5$ $\mathrm{ng} / \mathrm{mL})$ predicted worse 10 -year bRFS $(62 \%, 44 \%$ and $27 \%$, respectively). There was a significant benefit in OS rates (29). In our study, we found higher pre-RT PSA levels in the SRT group. The most important reason for this is delayed referral of the majority of the patients to the radiation oncology department for SRT despite explicit AUA and ASTRO guidelines.

However, the role of ADT in combination with ART or SRT remains debatable. GETUG 17 phase III, multicenter trial randomized the patients into two groups of postoperatively initiated RT after BCR versus RT plus 6-months of goserelin treatment. Five-year follow-up results demonstrated that SRT plus ADT had been associated with higher BCRfree survival rates as compared to RT alone without any difference in late toxicity (23). In contrast, in a retrospective study that compared RT alone vs RT plus hormone therapy, no benefit was observed in terms of OS or metastasis- free survival rates (30).We found that in the ART and SRT groups, $61.5 \%$ vs $56.1 \%$ of patients received hormone therapy without any statistically significant intergroup difference in terms of bDFS and side effects.

It has been shown in randomized studies that increasing the external RT dose improves oncological outcomes in localized PCa (31). Nevertheless, appropriate dose of postoperative RT to be delivered is debatable. Even though doses of $>70$ Gy potentially increase biochemical control rates, the treatment -related toxicities increase even with the use of advanced RT techniques such as IMRT or VMAT.

Riou et al. (32) compared CRT and IMRT, which they applied 68 Gy dose to the PB and observed rectum and bladder doses significantly decreased by IMRT planning without any grade $>2$ acute and late toxicities. In phase III trial SAKK 09/10, the patients with biochemical relapse but without any macroscopic disease were grouped as 64 vs 70 Gy RT. The patients were treated with 3-D CRT or IMRT, and acute GI and GU side effects were not seen between both groups while urinary symptoms worsened in the patients whom were applied 70 Gy (33). In most radiation oncology clinics, especially for SRT, total RT dose of 65-70.2 Gy is applied. In this study, the RT doses between 66 and 72 Gy were used, and higher number of patients received RT $\geq 70$ Gy in the whole cohort; without any intergroup difference in terms of bPFS or side effects. However, it is encouraging that despite higher doses, with IMRT/VMAT techniques, frequencies of late GI and GU side effects decreased.

Recently performed randomized studies have revealed that compared with RT targeted at prostate bed only, irradiation of PLNs during extended field RT can yield more improved treatment outcomes. Although only few studies have compared the toxicities of both treatment modalities so far, extended field RT has yielded better bPFS in patients with adverse pathologic features $(6,34)$. Deville et al. (35) stated 
that WPRT enhanced the toxicity profile, while the acute GI side effects were increasing, there was no difference in GU or late GI side effects compared with PBRT. They reported $61 \%$ grade $\geq 2$ acute GI and $22 \%$ GU toxicities, and $28 \%$ grade $\geq 2$ late GU and $3 \%$ GI side effects in their patients (35). Van Praet et al. (16) reported on toxicity of postoperative high-dose WPRT with ADT for PCa patients with lymph node metastases using IMRT technique in the ART and SRT settings. Incidence rates of acute and late GI toxicities were higher following WPRT compared to PB-RT $(\mathrm{p} \leq 0.041)$ despite comparable GU toxicity rates (16). In this study where RT was applied with VMAT technique, any statistically significant difference was not detected between WPRT vs PB-RT -only groups in terms of bPFS, but acute GI side effects were observed more frequently in the WPRT group.

\section{Study Limitations}

Our study's limitation is its retrospective, non-randomized planning applied to a mixed group of patients who were applied ART or SRT, with short-term or long-term ADT. Among the ART and SRT patients, some characteristics may differ especially in the time elapsed between surgery and RT application and the inclusion of patients with a higher pre-RT PSA levels $>0.5 \mathrm{ng} / \mathrm{mL}$ at the time of SRT.

A further limitation of this study is that treatment allocation (PB-RT versus WBRT) was not randomized; however, predefined risk-dependent criteria were used to allocate patients to the respective treatment modalities.

\section{Conclusion}

We present a comparison of oncologic outcomes and treatment-related side effects with adverse pathologic features in patients applied ART vs SRT. In patients with rising PSA, SRT was effective and applicable treatment modality with reduced toxicity. However, in high risk patients SRT results were as effective as ART outcomes. Serum PSA levels should be monitorized closely before treatment and taken consideration of administring early SRT would also delay the onset of treatment-related adverse events among these patients. As revealed in our study, clinical manifestations of treatment-related side effects could be reduced by using advanced treatment techniques like IMRT or VMAT.

\section{Ethics}

Ethics Committee Approval: This retrospective data analysis was approved by the ethics committee of our hospital (date: 20.11.2018, number: 1048).
Informed Consent: All patients signed a written informed consent.

Peer-review: Externally and internally peer-reviewed.

\section{Authorship Contributions}

Concept: S.D., Ç.N., E.M., Design: S.D., M.H.A., E.M., M.D., Data Collection or Processing: S.D., Ç.N., Analysis or Interpretation: M.H.A., E.M., Ç.N., Literature Search: S.D., M.D., M.H.A., Writing: S.D., M.D.

Conflict of Interest: No conflict of interest was declared by the authors.

Financial Disclosure: The authors declared that this study has received no financial support.

\section{References}

1. Kupelian PA, Potters L, Khuntia D, Ciezki JP, Reddy CA, Reuther AM, et al. Radical prostatectomy, external beam radiotherapy or $=72 \mathrm{~Gy}$, permanent seed implantation, or combined seeds/external beam radiotherapy for stage T1-T2 prostate cancer. Int J Radiat Oncol Biol Phys 2004;58(1):25-33.

2. Hull GW, Rabbani F, Abbas F, Wheeler TM, Kattan MW, Scardino PT. Cancer control with radical prostatectomy alone in 1,000 consecutive patients. J Urol 2002;167(2 Pt 1):528-534.

3. Vargas C, Kestin LL, Weed DW, Krauss D, Vicini FA, Martinez AA. Improved biochemical outcome with adjuvant radiotherapy after radical prostatectomy for prostate cancer with poor pathologic features. Int J Radiat Oncol Biol Phys 2005;61(3):714724 .

4. Pisansky TM, Thompson IM, Valicenti RK, D’Amico AV, Selvarajah S. Adjuvant and Salvage Radiotherapy after Prostatectomy: ASTRO/ AUA Guideline Amendment 2018-2019. J Urol 2019;202(3):533538.

5. Moghanaki D, Urdaneta AI, Karlin JD, Koontz BF, Anscher MS Management of postprostatectomy biochemical relapse with salvage radiotherapy: results of an international survey. Am J Clin Oncol 2016;39(1):64-68.

6. Spiotto MT, Hancock SL, King CR. Radiotherapy after prostatectomy: improved biochemical relapse-free survival with whole pelvic compared with prostate bed only for high-risk patients. Int J Radiat Oncol Biol Phys 2007;69(1):54-61.

7. Abdollah F, Karnes RJ, Suardi N, Cozzarini C, Gandaglia G, Fossati $\mathrm{N}$, et al. Impact of adjuvant radiotherapy on survival of patients with node-positive prostate cancer. J Clin Oncol 2014;32(35):39393947.

8. Bolla M, van Poppel H, Tombal B, Vekemans K, Pozzo LD, de Reijke TM, et al. Postoperative radiotherapy after radical prostatectomy for high-risk prostate cancer: late results of a randomised controlled trial (EORTC trial 22911) Lancet 2012;380(9858):20182027.

9. Thompson IM, Tangen CM, Paradelo J, Lucia MS, Miller G, Troyer D, et al. Adjuvant radiotherapy for pathological T3N0M0 prostate cancer significantly reduces risk of metastases and improves survival: late followup of a randomized clinical trial. J Urol 2009;181(3):956-962. 
10. Wiegel T, Bartkowiak D, Bottke D, Bronner C, Steiner U, Siegmann A, et al. Adjuvant radiotherapy versus wait-and-see after radical prostatectomy: 10-year follow-up of the ARO 96-02/AUO AP 09/95 Trial. Eur Urol 2014;66(2):243-250.

11. Daly T, Hickey BE, Lehman M, Francis DP, See AM. Adjuvant radiotherapy following radical prostatectomy for prostate cancer. Cochrane Database Syst Rev 2011;(12):CD007234.

12. Stephenson AJ, Scardino PT, Kattan MW, Pisansky TM, Slawin KM, Klein EA, et al. Predicting the outcome of salvage radiation therapy for recurrent prostate cancer after radical prostatectomy. J Clin Oncol 2007;25(15):2035-2041.

13. Trock BJ, Han M, Freedland SJ, Humphreys EB, DeWeese TL, Partin AW, et al. Prostate cancer-specific survival following salvage radiotherapy vs observation in men with biochemical recurrence after radical prostatectomy. JAMA 2008;299(23):2760-2769.

14. Cozzarini C, Fiorino C, Da Pozzo LF, Alongi F, Berardi G, Bolognesi A, et al. Clinical factors predicting late severe urinary toxicity after postoperative radiotherapy for prostate carcinoma: a singleinstitute analysis of 742 patients. Int J Radiat Oncol Biol Phys 2012;82(1):191-199.

15. Sowerby RJ, Gani J, Yim H, Radomski SB, Catton C. Late complications in men who have early or late radiotherapy after radical prostatectomy. Can Urol Assoc J 2014;8(7-8):253-258.

16. Van Praet C, Ost P, Lumen N, De Meerleer G, Vandecasteele K, Villeirs G, et al. Postoperative high-dose pelvic radiotherapy for $\mathrm{N}+$ prostate cancer: toxicity and matched case comparison with postoperative prostate bed-only radiotherapy. Radiother Oncol 2013;109(2):222-228.

17. Roach M, Marquez C, Yuo HS, Narayan P, Coleman L, Nseyo UO, et al. Predicting the risk of lymph node involvement using the pretreatment prostate specific antigen and gleason score in men with clinically localized prostate cancer. Int J Radiat Oncol Biol Phys 1994;28(1):33-37.

18. Michalski JM, Lawton C, El Naqa I, Ritter M, O'Meara E, Seider MJ, et al. Development of RTOG Consensus Guidelines for the Definition of the Clinical Target Volume for Postoperative Conformal Radiation Therapy for Prostate Cancer. Int J Radiat Oncol Biol Phys 2010;76(2):361-368.

19. Cox JD, Stetz J, Pajak TF. Toxicity criteria of the Radiation Therapy Oncology Group (RTOG) and the European Organization for Research and Treatment of Cancer (EORTC). Int J Radiat Oncol Biol Phys 1995;31(5):1341-1346.

20. Thompson IM, Valicenti RK, Albertsen P, Davis BJ, Goldenberg SL, Hahn C, et al. Adjuvant and salvage radiotherapy after prostatectomy: AUA/ASTRO guideline. J Urol 2013;190(2):441-449.

21. Valicenti RK, Thompson I Jr, Albertsen P, Davis BJ, Goldenberg SL, Wolf JS, et al. Adjuvant and salvage radiation therapy after prostatectomy: American society for radiation oncology/american urological association guidelines. Int J Radiat Oncol Biol Phys 2013;86(5):822-828.

22. Shaikh MP, Alite F, Wu MJ, Solanki AA, Harkenrider MM. Adjuvant radiotherapy versus wait-and-see strategy for pathologic T3 or margin-positive prostate cancer: a meta-analysis. Am J Clin Oncol 2018;41(8):730-738.

23. Carrie C, Hasbini A, de Laroche G, Richaud P, Guerif S, Latorzeff I, et al. Salvage radiotherapy with or without short-term hormone therapy for rising prostate-specific antigen concentration after radical prostatectomy (GETUG-AFU 16): a randomised, multicentre, open-label phase 3 trial. Lancet Oncol 2016;17(6):747756.

24. Pearse M, Fraser-Browne C, Davis ID, Duchesne GM, Fisher R, Frydenberg M, et al. A phase III trial to investigate the timing of radiotherapy for prostate cancer with high-risk features: background and rationale of the radiotherapy - adjuvant versus early salvage (RAVES) trial. BJU Int 2014;113 Suppl 2:7-12.

25. Parker C, Clarke N, Logue J, Payne H, Catton C, Kynaston H, et al. RADICALS Trial Management Group. RADICALS (Radiotherapy and Androgen Deprivation in Combination after Local Surgery). Clin Oncol (R Coll Radiol) 2007;19(3):167-171.

26. Vale CL, Fisher D, Kneebone A, Parker C, Pearse M, Richaud P, et al. Adjuvant or early salvage radiotherapy for the treatment of localised and locally advanced prostate cancer: a prospectively planned systematic review and meta-analysis of aggregate data. Lancet 2020;396(10260):1422-1431.

27. Jereczek-Fossa BA, Zerini D, Vavassori A, Fodor C, Santoro L, Minissale A, et al. Sooner or later? Outcome analysis of 431 prostate cancer patients treated with postoperative or salvage radiotherapy. Int J Radiat Oncol Biol Phys 2009;74(1):115-125.

28. Feng M, Hanlon AL, Pisansky TM, Kuban D, Catton CN, Michalski JM, et al. Predictive factors for late genitourinary and gastrointestinal toxicity in patients with prostate cancer treated with adjuvant or salvage radiotherapy. Int J Radiat Oncol Biol Phys 2007;68(5):1417-1423.

29. Abugharib A, Jackson WC, Tumati V, Dess RT, Lee JY, Zhao SG, et al. Very early salvage radiotherapy improves distant metastasis-free survival. J Urol 2017;197(3 Pt 1):662-668.

30. Jackson WC, Schipper MJ, Johnson SB, Foster C, Li D, Sandler $\mathrm{HM}$, et al. Duration of androgen deprivation therapy influences outcomes for patients receiving radiation therapy following radical prostatectomy. Eur Urol 2016;69(1):50-57.

31. Zietman AL, DeSilvio ML, Slater JD, Rossi CJ Jr, Miller DW, Adams JA, et al. Comparison of conventional-dose vs high-dose conformal radiation therapy in clinically localized adenocarcinoma of the prostate: a randomized controlled trial. JAMA 2005;294(10):12331239.

32. Riou O, Laliberte B, Azria D, Menkarios C, Moscardo CL, Dubois $\mathrm{JB}$, et al. Implementing intensity modulated radiotherapy to the prostate bed:dosimetric study and early clinical results. Med Dosim 2013;38(2):117-121.

33. Ghadjar P, Hayoz S, Bernhard J, Zwahlen DR, Stein J, Hölscher T, et al. Impact of dose intensified salvage radiation therapy on urinary continence recovery after radical prostatectomy: Results of the randomized trial SAKK 09/10. Radiother Oncol 2018;126(2):257-262.

34. Pollack A, Karrison TG, Balogh AG Jr, Low D, Bruner DW, Wefel JS, et al. Short term androgen deprivation therapy without or with pelvic lymph node treatment added to prostate bed only salvage radiotherapy: the NRG Oncology/RTOG 0534 SPPORT Trial. Int J Radiat Oncol Biol Phys 2018;102(5):1605.

35. Deville C, Vapiwala N, Hwang WT, Lin H, Bar Ad V, Tochner Z, et al. Comparative Toxicity and Dosimetric Profile of Whole-Pelvis Versus Prostate Bed-Only Intensity-Modulated Radiation Therapy After Prostatectomy. Int J Radiat Oncol Biol Phys 2012;82(4):13891396. 